\title{
Bisphenol A Analogues in Food and Their Hormonal and Obesogenic Effects: A Review
}

\author{
Natalia Andújar ${ }^{1,+}{ }^{,}$Yolanda Gálvez-Ontiveros ${ }^{1,+}$, Alberto Zafra-Gómez ${ }^{2}$, Lourdes Rodrigo ${ }^{3}$, \\ María Jesús Álvarez-Cubero ${ }^{4,5, *}$, Margarita Aguilera 6,7 (D), Celia Monteagudo 1,7,t(D) \\ and Ana Rivas 1,7,+ \\ 1 Department of Nutrition and Food Science, University of Granada, Campus of Cartuja, 18071 Granada, Spain \\ Department of Analytical Chemistry, University of Granada, Campus of Fuentenueva, 18071 Granada, Spain \\ Department of Legal Medicine and Toxicology, University of Granada, 18071 Granada, Spain \\ Department of Biochemistry \& Molecular Biology III, University of Granada, PTS, 18016 Granada, Spain \\ 5 GENYO, Pfizer-University of Granada-Junta de Andalucía Centre for Genomics and Oncological Research, \\ Av. de la Ilustración 114, 18016 Granada, Spain \\ 6 Department of Microbiology, Faculty of Pharmacy, University of Granada, Campus of Cartuja, \\ Granada 18071, Spain \\ 7 Instituto de Investigación Biosanitaria ibs, 18016, Granada, Spain \\ * Correspondence: mjesusac@ugr.es; Tel.: +34-958-715-500; Fax: +34-958-637-071 \\ + These authors have contributed equally to the work.
}

Received: 16 July 2019; Accepted: 21 August 2019; Published: 6 September 2019 updates

\begin{abstract}
Bisphenol A (BPA) is the most well-known compound from the bisphenol family. As BPA has recently come under pressure, it is being replaced by compounds very similar in structure, but data on the occurrence of these BPA analogues in food and human matrices are limited. The main objective of this work was to investigate human exposure to BPA and analogues and the associated health effects. We performed a literature review of the available research made in humans, in in vivo and in vitro tests. The findings support the idea that exposure to BPA analogues may have an impact on human health, especially in terms of obesity and other adverse health effects in children.
\end{abstract}

Keywords: bisphenol A analogues; food; obesogenic effect

\section{Introduction}

Endocrine disruptors are compounds that alter the normal functioning of the endocrine system, and their bioaccumulation in humans may cause adverse health effects [1-3]. Bisphenol A (BPA) is a well-known endocrine disruptor, industrially produced, largely used as a component of epoxy resins and polycarbonate plastics [4,5]. BPA-based plastics and resins are used in the manufacturing of food contact material such as packaging, crockery, and thermic paper. Human exposure to BPA occurs mainly through diet (food and food contact materials) [6]. Moreover, BPA has also been found in plastic food containers, epoxy coatings in metal cans, kitchenware toys, medical devices, and dental composites and sealants [4,7-10].

In humans, BPA has proven to have developmental, reproductive, cardiovascular, immune, and metabolic effects [11]. In 2017, BPA was listed in the substances of very high concern list of the European Chemical Agency (ECHA). In view of the recent regulations that further restrict the use of BPA in food contact materials [12-16], food packaging companies are exploring substitutes to gradually eliminate BPA from their products $[10,17,18]$.

Commercialization of BPA-free labeled products is increasing, while BPA analogues are being increasingly used in the manufacturing of consumer products [10]. BPA analogues share the basic 
bisphenol structure of two benzene rings separated by a short carbon or other chemical chain [10] (Figure 1). Bisphenol S (BPS), bisphenol F (BPF), bisphenol B (BPB), bisphenol E (BPE), and bisphenol $\mathrm{AF}(\mathrm{BPAF})$ are chosen by the industry as a replacement for BPA in the production of polycarbonates and epoxy resins $[10,19,20]$ for the manufacturing of industrial and consumer products $[21,22]$. There are a limited number of studies on the BPA analogues' hormonal effects, but most show that they have similar health concerns as BPA [23-26]. In 2002, we demonstrated the endocrine-disrupting activity of BPA analogues in the expression of estrogen-controlled genes [27]. Furthermore, some of the BPA substitutes seem to have more estrogenic effects than BPA [28]. Despite the regulatory actions taken in recent years, one potential hazardous chemical is being replaced with others with similar activity and health outcomes.<smiles>CC(C)(c1ccc(O)cc1)c1ccc(O)cc1</smiles>

Bisphenol A (BPA)<smiles>CC(c1ccc(O)cc1)c1ccc(O)cc1</smiles>

Bisphenol E (BPE)<smiles>O=S(=O)(c1ccc(O)cc1)c1ccc(O)cc1</smiles>

Bisphenol S (BPS)<smiles>Oc1ccc(C=Cc2ccc(O)cc2)cc1</smiles>

Bisphenol F (BPF)<smiles>CCC(C)(c1ccc(O)cc1)c1ccc(O)cc1</smiles>

Bisphenol B (BPB)<smiles>Oc1ccc(C(c2ccc(O)cc2)(C(F)(F)F)C(F)(F)F)cc1</smiles>

Bisphenol AF (BPAF)

Figure 1. Bisphenols with endocrine-disrupting activity. Prepared by author based on Gallart-Ayala et al., 2011 [29].

The health effects of BPA analogues have been reported recently in different studies [28,30]. Pelch et al., (2019) [25] concluded in a recent review that BPA analogues have health or toxicological effects at concentrations similar to or lower than BPA. BPA analogues have proven to have bone [31], reproductive [32], metabolic [33], oxidative stress [34], and neurological effects [35].

The considerable use of BPA analogues and their potential health risks require studies to better understand the complex and widespread routes of human exposure. The objective of this work was to identify data on the presence of BPA analogues in food, human biomonitoring data, and health effects of these chemicals, especially those related to obesogenic outcomes. This was addressed by a literature review of the available research. We hope the information in this review may be useful to move to new regulations based on classes of chemicals rather than on an individual chemical approach. 


\section{Methods}

A review of the available literature was conducted in March 2019. PubMed/Medline and Scopus databases were searched using the keywords "Bisphenol A analogues", "Bisphenol A substitutes", "food", "hormone effect", "biological samples", "health", and "obesogenic effect". Data published between 1999 and 2019 were considered.

Figure 2 shows the Preferred Reporting Items for Systematic Reviews and Meta-Analyses (PRISMA) flow diagram of the literature search [36]. Study selection consisted of two screening phases. The first selection was based on title and abstract screening, and the second selection was based on a full-text screening. One reviewer (N.A.) conducted the two screening phases, and in case of doubt, a second reviewer (A.R.) was consulted. The literature search yielded 572 studies. Studies were selected for full-text screening when they met the inclusion criteria. In case of doubt, articles were also analyzed based on their full text. Cross references were checked for additional references. Studies were excluded after the analysis of full text if they met one of the following criteria: (a) not English language; (b) not outcome of interest, and (c) not about the subject of the study.

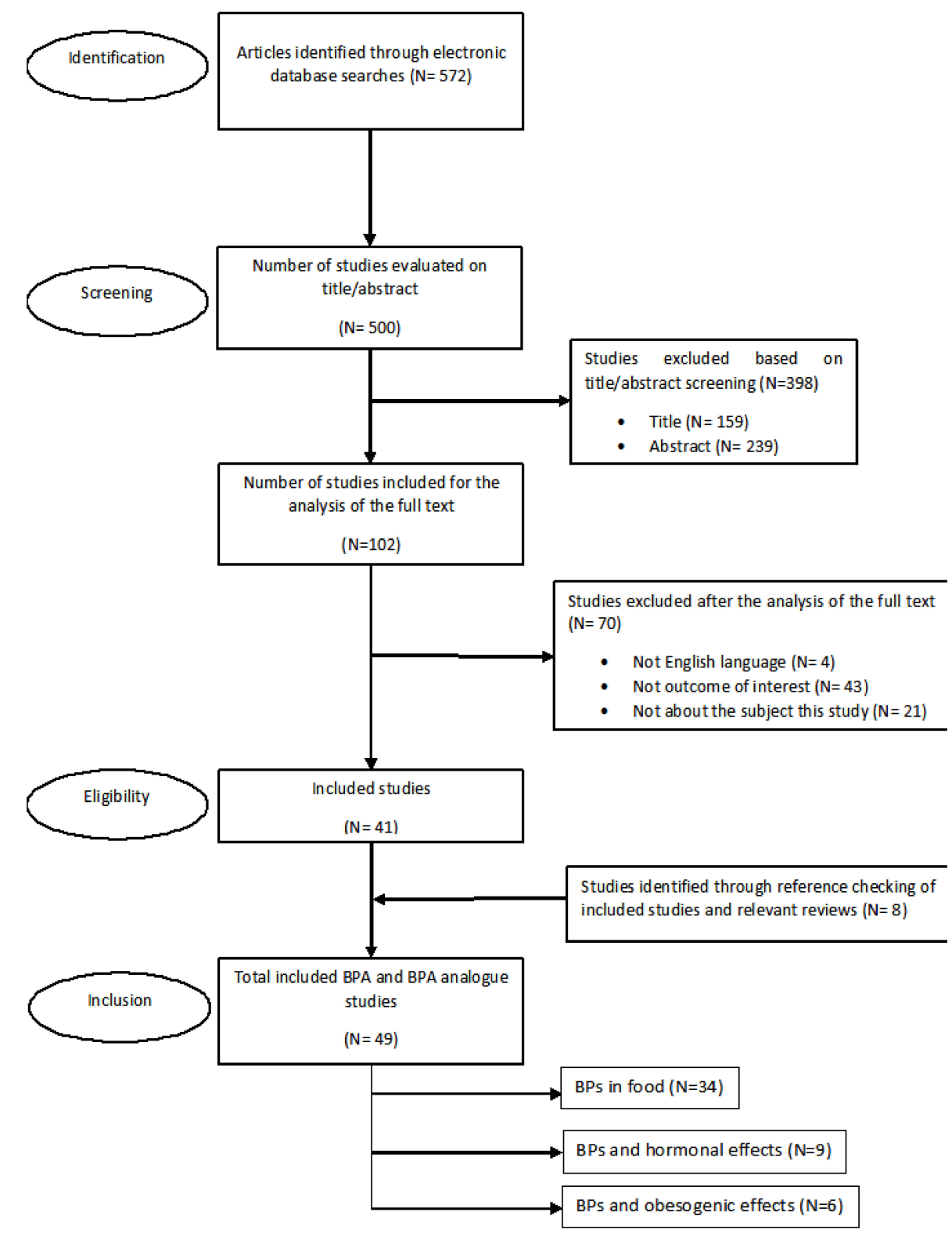

Figure 2. PRISMA flow diagram of the literature search. 


\section{Bisphenol A Analogues in Food}

There is little information regarding the occurrence of bisphenol analogues (BPs) in foodstuffs. Liao and Kannan [37], in a study performed in the United States, determined the presence of BPA, $\mathrm{BPF}$, and BPS $(N=267)$ in nine categories of foodstuffs and found that $75 \%$ of the samples contained BPs, with total concentrations ranging between below the limit of quantification (LOQ) and $1130 \mathrm{ng} / \mathrm{g}$ fresh weight (4.38 ng/g overall mean value). The highest overall mean concentration (sum of eight BPs) was detected in preserved and ready-to-eat foods. The highest BPF and bisphenol P (BPP) concentrations were $1130 \mathrm{ng} / \mathrm{g}$ and $237 \mathrm{ng} / \mathrm{g}$, respectively, and were found in a sample of mustard and ginger. In contrast, BPs in beverages and fruits were found in concentrations of $0.341 \mathrm{ng} / \mathrm{g}$ and $0.698 \mathrm{ng} / \mathrm{g}$, respectively. Higher levels of individual and total BPs were detected in canned food than in foods that came in plastic, glass, or paper containers.

Liao and Kannan [38], in a study performed in China, determined the presence of eight BPs $(N=289)$ in 13 categories of foodstuffs using high-performance liquid chromatography-tandem mass spectrometry (HPLC-MS/MS). The most frequently found BPs were BPA and BPF, which were detected at mean value concentrations of $4.94 \mathrm{ng} / \mathrm{g}$ and $2.50 \mathrm{ng} / \mathrm{g}$ fresh weight, respectively. The highest overall concentration (sum of eight BPs) was found in canned products $(27.0 \mathrm{ng} / \mathrm{g}$ ), followed by fish and seafood $(16.5 \mathrm{ng} / \mathrm{g})$, and beverages $(15.6 \mathrm{ng} / \mathrm{g})$. In contrast, the lowest overall concentration was found in milk and dairy products, cooking oils, and eggs ( $2-3 \mathrm{ng} / \mathrm{g})$. Higher total concentration levels were detected in canned foodstuffs $(56.9 \mathrm{ng} / \mathrm{g})$ than in foods coming in glass $(0.43 \mathrm{ng} / \mathrm{g})$, paper $(11.9 \mathrm{ng} / \mathrm{g})$, or plastic $(6.40 \mathrm{ng} / \mathrm{g})$ containers.

Other studies have reported on the presence of BPA analogues in canned vegetables, fruits, and soft drinks [29,39] as well as in honey [40,41], fish [41], and mustard [42]. BPF has been found in mustard from white mustard seeds in $\mathrm{mg} \mathrm{kg}^{-1}$ levels and is a natural reaction product formed during its preparation. Mustard is one of the most widely used condiments worldwide and, according to some authors, it is the main source of BPF in humans, in Europe, and probably worldwide [42]. In addition to BPA, bisphenol A diglycidyl ether (BADGE) and bisphenol F diglycidyl ether (BFDGE) have been detected in different milk samples from supermarkets and dairy farms [43], and BPF and BPS have been detected in dairy products, meat and meat products, vegetables, and cereals [37].

Although BPA is the most studied BP, BADGE and BFDGE have also been detected in drinking water as these BPs are commonly used in the epoxy coatings applied in drinking water distribution systems. BPs from the coatings may be exposed to chemical oxidants (disinfectants) that have the potential to form by-products with enhanced or reduced estrogenic activity than the parent compounds [44]. Exposure to free chlorine results in rapid BP degradation (half-lives of BPs are between $<1 \mathrm{~min}$ to $35 \mathrm{~min}$ ) under typical conditions [44].

There is an increasing amount of research linking long-term, low-level exposure to BPA in early life and adverse health effects in infants and fetuses [22]. Breast milk is the main source of energy for babies under six months and therefore it may be used as a proxy of the internal exposure levels in mothers and fetuses. Niu et al. (2017) [22] found BPA, BPF, BPS, and BPAF in breast milk samples, with BPA being the most abundant BP, followed by BPF. Recently, our research group has reported on the presence of BPB, BPS, BPE, and BPP in baby food samples [10].

Table 1 summarizes the BPs found in different food samples analyzed, their concentrations, and the analytical techniques used for detection. 
Table 1. Bisphenol analogues (BPs) found in food samples using different analytical techniques.

\begin{tabular}{|c|c|c|c|c|}
\hline Reference & Food & Bisphenol & Concentration & Analytic Technique \\
\hline Abou-Omar et al., 2017 [45] & 27 olive oils & BPA & $\begin{array}{c}\text { non-plastic packaging Mean }=333 \mu \mathrm{gg} / \mathrm{kg} \\
\text { plastic packaging Mean }=150 \mu \mathrm{g} / \mathrm{kg}\end{array}$ & $\begin{array}{l}\text { High Performance Liquid Chromatography with Fluorescence } \\
\text { Detection (HPLC-FLD) }\end{array}$ \\
\hline Alabi et al., 2014 [46] & $\begin{array}{c}\text { Canned vegetables (mushroom, red pepper, olive, green beans, } \\
\text { asparagus), legumes (chickpeas, lentils), canned fruits (pineapple, } \\
\text { peach), canned fish and other seafood (mackerel, mussels, tuna, } \\
\text { cockles), canned meat products (tripe, meat ball), and canned } \\
\text { grains (sweet corn) }\end{array}$ & $\begin{array}{c}\text { BPA } \\
\text { BPF } \\
\text { BADGE } \\
\text { BPE } \\
\text { BPB } \\
\text { BFDGE }\end{array}$ & $\begin{array}{l}13-241 \mu \mathrm{\mu g} / \mathrm{kg} \\
\mathrm{ND} \\
7.1 \mu \mathrm{g} / \mathrm{kg} \\
\mathrm{ND} \\
25-40 \mu \mathrm{gg} / \mathrm{kg} \\
21-314 \mu \mathrm{gg} / \mathrm{kg}\end{array}$ & HPLC-FLD \\
\hline Cacho et al., 2012 [5] & Canned beverages and filling liquids of canned vegetables & $\begin{array}{l}\text { BPA } \\
\text { BPF } \\
\text { BPZ }\end{array}$ & $\begin{array}{c}0.10-0.35 \mu \mathrm{g} / \mathrm{L} \\
0.4 \mu \mathrm{g} / \mathrm{L} \\
\mathrm{ND}\end{array}$ & $\begin{array}{l}\text { Stir bar sorptive extraction combined with thermal desorption } \\
\text { (Gas chromatography-mass spectrometry, GC-MS) }\end{array}$ \\
\hline Cesen et al., 2016 [40] & 36 honey samples & $\begin{array}{l}\text { BPA } \\
\text { BPAF } \\
\text { BPE } \\
\text { BPF } \\
\text { BPS } \\
\text { BPZ }\end{array}$ & $\begin{array}{l}\text { Mean }=107 \mathrm{ng} / \mathrm{g} \\
\text { Mean }=53.5 \mathrm{ng} / \mathrm{g} \\
\text { Mean }=12.8 \mathrm{ng} / \mathrm{g} \\
\text { Mean }=31.6 \mathrm{ng} / \mathrm{g} \\
\text { Mean }=302 \mathrm{ng} / \mathrm{g} \\
\text { Mean }=28.4 \mathrm{ng} / \mathrm{g}\end{array}$ & GC-MS \\
\hline Cirillo et al., 2015 [47] & Infant formulas & BPA & Median $=0.015 \mu \mathrm{g} / \mathrm{g}$ & HPLC-FLD \\
\hline Cunha et al., 2011 [48] & 30 beverages and 7 powdered infant formulas & $\begin{array}{l}\text { BPA } \\
\text { BPB }\end{array}$ & $\begin{array}{l}\text { Mean }=0.115 \mu \mathrm{g} / \mathrm{L} \\
\text { Mean }=2.365 \mu \mathrm{g} / \mathrm{L}\end{array}$ & Dispersive liquid-liquid microextraction and GC-MS \\
\hline Cunha et al., 2012 [49] & $\begin{array}{l}47 \text { canned seafood samples (22 tuna, } 10 \text { sardines, } 3 \text { mackerel, } 3 \\
\text { squid, } 3 \text { octopus, } 2 \text { mussels, } 1 \text { eel, } 1 \text { anchovy, } 1 \text { cod) }\end{array}$ & $\begin{array}{l}\text { BPA } \\
\text { BPB }\end{array}$ & $\begin{array}{c}1.0-99.9 \mu \mathrm{g} / \mathrm{kg} \\
21.8 \mu \mathrm{g} / \mathrm{kg} \text { (only one sample) }\end{array}$ & $\begin{array}{l}\text { QuEChERS (dispersive solid-phase cleanup) combined with } \\
\text { dispersed liquid-liquid microextraction and GC-MS }\end{array}$ \\
\hline Cunha and Fernandes, 2013 [50] & 20 canned vegetables and 19 canned fruits & $\begin{array}{l}\text { BPA } \\
\text { BPB }\end{array}$ & $\begin{array}{l}\text { Mean }=265.6 \mu \mathrm{g} / \mathrm{kg} \\
\text { Mean }=3.4 \mu \mathrm{g} / \mathrm{kg}\end{array}$ & QuEChERS combined with GC-MS \\
\hline Fasano et al., 2015 [51] & $\begin{array}{l}3 \text { packed grated cheese, } 2 \text { meat, } 2 \text { fish, and } 2 \text { vegetables broths, } 2 \\
\text { white and } 2 \text { red wines, } 4 \text { pasta, } 4 \text { rice, } 3 \text { chicken and vegetables }\end{array}$ & BPA & $0.72-218 \mathrm{ng} / \mathrm{g}$ & QuEChERS combined with GC-MS \\
\hline Feshin et al., 2012 [52] & $\begin{array}{l}\text { Fruit and vegetable puree, canned fruit and vegetables; milk, } \\
\text { meat puree, and canned meat }\end{array}$ & BPA & $2.15-42.91 \mathrm{ng} / \mathrm{g}$ & GC-MS \\
\hline Gallart-Ayala et al., 2011a [39] & 11 canned soft drinks (soda, cola, tea, energy drink, and beer) & $\begin{array}{l}\text { BPA } \\
\text { BPF }\end{array}$ & $\begin{array}{l}44-607 \mathrm{ng} / \mathrm{L} \\
218-141 \mathrm{ng} / \mathrm{L}\end{array}$ & $\begin{array}{l}\text { Liquid chromatography-tandem mass spectrometry } \\
\text { (LC-MS/MS) }\end{array}$ \\
\hline Gallart-Ayala et al., 2011b [29] & $\begin{array}{l}6 \text { canned foods (vegetables and fruits) and } 7 \text { canned beverages } \\
\text { (soda, cola, tea, and tonic drink) }\end{array}$ & $\begin{array}{l}\text { BADGE } \\
\text { BFDGE }\end{array}$ & $\begin{array}{l}2.3-675 \mu \mathrm{\mu g} / \mathrm{kg} \\
\mathrm{ND}\end{array}$ & LC-MS/MS \\
\hline Gallo et al., 2017 [18] & 40 canned energy drink samples & $\begin{array}{c}\text { BPA } \\
\text { BADGE } \\
\text { BFDGE }\end{array}$ & $\begin{array}{c}0.50-3.3 \mathrm{ng} / \mathrm{ml} \\
0.50-19.4 \mathrm{ng} / \mathrm{ml} \\
0.50-0.60 \mathrm{ng} / \mathrm{ml}\end{array}$ & $\begin{array}{l}\text { Ultra-high performance liquid chromatography linked with } \\
\text { fluorescence detection (UPLC-FLD) }\end{array}$ \\
\hline García-Córcoles et al., 2018 [10] & 15 baby food samples & $\begin{array}{l}\text { BPS } \\
\text { BPB } \\
\text { BPP }\end{array}$ & $\begin{array}{c}11.7-49.2 \mathrm{ng} / \mathrm{g} \\
1.1-8.5 \mathrm{ng} / \mathrm{g} \\
1-7.7 \mathrm{ng} / \mathrm{g}\end{array}$ & GC-MS/MS \\
\hline Grumetto et al., 2013 [53] & $\begin{array}{l}68 \text { milk samples were packed in Tetra Pack or Tetra Brix boxes or } \\
\text { in plastic bottles (PET, PEHD) }\end{array}$ & $\begin{array}{l}\text { BPA } \\
\text { BPF } \\
\text { BPB }\end{array}$ & $\begin{array}{c}5.21-14.0 \mathrm{ng} / \mathrm{ml} \\
0.1-26.2 \mathrm{ng} / \mathrm{ml} \\
16.0-67.0 \mathrm{ng} / \mathrm{ml}\end{array}$ & LC-FLD \\
\hline
\end{tabular}


Table 1. Cont.

\begin{tabular}{|c|c|c|c|c|}
\hline Reference & Food & Bisphenol & Concentration & Analytic Technique \\
\hline Kuo and Ding, 2004 [54] & 4 soy-based infant formula powders & BPA & $45-113 \mathrm{ng} / \mathrm{g}$ & GC-MS \\
\hline $\begin{array}{l}\text { Lapviboonsuk and } \\
\text { Leepipatpiboon, } 2014 \text { [55] }\end{array}$ & 3 canned tuna & BADGE & ND & QuEChERS and HPLC \\
\hline Liao and Kannan, 2013 [37] & $\begin{array}{l}31 \text { beverages, } 29 \text { dairy products, } 5 \text { fats and oils, } 23 \text { fish and } \\
\text { seafood, } 48 \text { cereals and cereal products, } 51 \text { meat and meat } \\
\text { products, } 20 \text { fruits and canned fruits, } 45 \text { vegetables and canned } \\
\text { vegetables, and } 15 \text { "others" }\end{array}$ & $\begin{array}{c}\text { BPA } \\
\text { BPAF } \\
\text { BPAP } \\
\text { BPB } \\
\text { BPF } \\
\text { BPP } \\
\text { BPS } \\
\text { BPZ }\end{array}$ & $\begin{array}{c}0.285-9.97 \mathrm{ng} / \mathrm{g} \\
0.005-0.021 \mathrm{ng} / \mathrm{g} \\
0.005-0.185 \mathrm{ng} / \mathrm{g} \\
0.013-0.017 \mathrm{ng} / \mathrm{g} \\
0.025-4.63 \mathrm{ng} / \mathrm{g} \\
0.013-0.562 \mathrm{ng} / \mathrm{g} \\
0.005-0.609 \mathrm{ng} / \mathrm{g} \\
0.025-0.076 \mathrm{ng} / \mathrm{g}\end{array}$ & HPLC-MS/MS \\
\hline Pardo et al., 2006 [56] & 10 canned pig meat & $\begin{array}{l}\text { BADGE } \\
\text { BFDGE }\end{array}$ & $\begin{array}{c}83-87 \mathrm{ng} / \mathrm{g} \\
96-101 \mathrm{ng} / \mathrm{g}\end{array}$ & $\begin{array}{l}\text { Reversed-phase HPLC coupled to atmospheric pressure } \\
\text { chemical ionization tandem mass spectrometry }\end{array}$ \\
\hline Rastkari et al., 2010 [57] & 12 canned tomato paste and 12 canned corn & $\begin{array}{l}\text { BPA } \\
\text { BPF }\end{array}$ & $\begin{array}{l}0.90-47.38 \mu \mathrm{g} / \mathrm{kg} \\
0.89-47.11 \mu \mathrm{g} / \mathrm{kg}\end{array}$ & GC-MS \\
\hline Rauter et al., 1999 [58] & 142 canned oily foods & BADGE & $0.02-1.5 \mathrm{mg} / \mathrm{kg}$ & HPLC combined with GC-MS \\
\hline Sadeghi et al., 2015 [41] & $\begin{array}{l}\text { Canned fruits (pineapple, peach), canned vegetables (tomato), } \\
\text { powdered milk, soft drinks, honey, and fish }\end{array}$ & BPA & $0.9-8.3 \mathrm{ng} / \mathrm{g}$ & HPLC-FLD \\
\hline Simoneau et al., 2012 [59] & 449 plastic baby bottles & BPA & $0.5-1000 \mu \mathrm{g} / \mathrm{kg}$ & HPLC and UPLC-MS combined with LC-MS \\
\hline Viñas et al., 2010 [60] & $\begin{array}{l}\text { Canned foods (peas, peas with carrots, sweet corn, artichoke, } \\
\text { mushroom, bean shoot, and mixed vegetables) }\end{array}$ & $\begin{array}{l}\text { BPA } \\
\text { BPS }\end{array}$ & $\begin{array}{l}11.7-321 \mathrm{ng} / \mathrm{mL} \text { supernatant } \\
12.9-77.7 \mathrm{ng} / \mathrm{g} \text { food } \\
8.90-175 \mathrm{ng} / \mathrm{g} \text { supernatant } \\
34.1-36.1 \mathrm{ng} / \mathrm{g} \text { foods }\end{array}$ & GC-MS in the selected ion monitoring \\
\hline Xionga et al., 2018 [43] & Milk samples from supermarkets and dairy farms & $\begin{array}{l}\text { BPA } \\
\text { BADGE } \\
2 \mathrm{H} 2 \mathrm{O} \\
\text { BFDGE } \\
2 \mathrm{H} 2 \mathrm{O}\end{array}$ & $\begin{array}{c}14.31 \mu \mathrm{g} / \mathrm{kg} \\
15.80 \mu \mathrm{g} / \mathrm{kg} \\
16.23-17.82 \mu \mathrm{g} / \mathrm{kg}\end{array}$ & QuEChERS and HPLC-FLD \\
\hline Yang et al., 2014 [61] & 2 coconut juice samples & $\begin{array}{c}\text { BPS } \\
\text { BPA } \\
\text { BPF } \\
\text { BPAF }\end{array}$ & $\begin{array}{c}0.019-0.036 \mathrm{ng} / \mathrm{g} \\
0.23-12 \mathrm{ng} / \mathrm{g} \\
0.39 \mathrm{ng} / \mathrm{g} \\
0.013-0.052 \mathrm{ng} / \mathrm{g} \\
\end{array}$ & LC-MS/MS \\
\hline Zhang et al., 2010 [62] & Canned fish and meat & $\begin{array}{l}\text { BADGE } \\
\text { BFDGE }\end{array}$ & $\begin{array}{r}58.76-140.72 \mathrm{ng} / \mathrm{g} \\
40.57-77.64 \mathrm{ng} / \mathrm{g}\end{array}$ & HPLC-FLD \\
\hline Zoller et al., 2016 [42] & 61 mustard samples & BPF & Mean $1.85 \mathrm{mg} / \mathrm{kg}$ & $\begin{array}{l}\text { LC-MS/MS, liquid chromatography/high resolution mass } \\
\text { spectrometry (LC-HRMS) and gas chromatography/high } \\
\text { resolution mass spectrometry GC-HRMS) }\end{array}$ \\
\hline Zou et al., 2012 [45] & $\begin{array}{l}3 \text { canned porridge, } 3 \text { canned mushroom, } 3 \text { canned Cirrhinus } \\
\text { molitorella, } 3 \text { canned tuna, } 3 \text { canned anchovy, } 3 \text { canned pork, } 3 \\
\text { canned pork sauce, } 3 \text { canned peanut butter }\end{array}$ & $\begin{array}{l}\text { BADGE } \\
\text { BFDGE }\end{array}$ & $\begin{array}{l}1.78-88.08 \mathrm{ng} / \mathrm{g} \\
2.13-32.96 \mathrm{ng} / \mathrm{g}\end{array}$ & UPLC-MS/MS \\
\hline
\end{tabular}

ND, not detected; HPLC-FLD, high-performance liquid chromatography, fluorescence detector; GC, gas chromatography; MS, mass spectrometry; UPLC, ultra-performance liquid chromatography; HRMS, high-resolution mass spectrometry. 


\section{Bisphenol A Analogues in Biological Samples and Their Hormonal Effects}

Data on BPA analogue occurrence in human samples are scarce. Human uridine $5^{\prime}$-diphosphateglucuronosyltransferases are able to rapidly metabolize BPA analogues into the corresponding BPAglucuronide (UGTs) [63-65]. BPA-glucuronides are rapidly excreted in urine in rats and humans [66] and determination of urinary levels is considered a good biomarker of exposure to BPs [67].

Liao et al., (2012) [23] determined the total concentration of BPS in 315 urine samples, collected from the U.S. and different Asian countries, and detected BPS in $81 \%$ of the samples analyzed with variations between countries. BPS concentrations were between below the LOQ $(0.02 \mathrm{ng} / \mathrm{mL})$ and $21 \mathrm{ng} / \mathrm{mL}$ (geometric mean (GM): $0.168 \mathrm{ng} / \mathrm{mL}$ ). The highest GM concentration of BPS was detected in samples from Japan $(1.18 \mathrm{ng} / \mathrm{mL})$.

Ye et al., (2015) [68] determined the concentration of BPA, BPS, BPF, and BPAF in 616 archived urine samples collected anonymously from volunteers during eight years. BPA was the most frequently detected chemical (74\%-99\%), whereas BPAF was detected in fewer than $3 \%$ of the samples. The detection frequencies were in the ranges of $74 \%-99 \%$ for $\mathrm{BPA}, 42 \%-88 \%$ for $\mathrm{BPF}$, and $19 \%-74 \%$ for BPS. GM concentrations were in the ranges of $0.36-2.07 \mu \mathrm{g} / \mathrm{L}$ for BPA, $0.15-0.54 \mu \mathrm{g} / \mathrm{L}$ for BPF, and $<0.1$ to $0.25 \mu \mathrm{g} / \mathrm{L}$ for BPS. Although BPF concentrations were generally lower than other BPs, the 95th percentile concentration of BPF was similar or higher than that of BPA in most of the samples. The authors conclude that the significant changes in GM concentrations of BPA and BPS are consistent with a decline in BPA exposure and an increase in BPS exposure.

Lehmler et al., (2018) [69] investigated the association between the presence of BPA, BPF, and BPS in urine samples from adults $(N=1808)$ and children $(N=868)$ and different demographic and lifestyle variables; the BPA, BPS, and BPF levels were $95.7 \%, 89.4 \%$, and $66.5 \%$, respectively. In adults, the median levels of BPA were higher $(1.24 \mu \mathrm{g} / \mathrm{L})$ than BPF and BPS levels $(0.35$ and $0.37 \mu \mathrm{g} / \mathrm{L}$, respectively). In children, the median BPA levels were also higher $(1.25 \mu \mathrm{g} / \mathrm{L})$ than BPF and BPS levels $(0.32$ and $0.29 \mu \mathrm{g} / \mathrm{L}$, respectively). The study revealed associations between the different BPs and gender, race, income, physical activity, smoking, and alcohol intake.

Exposure of pregnant women to BPs is a particular concern, as these chemicals pass from mother to infant via breast milk, making this matrix a main target for exposure assessment of critical subpopulations. In this framework, Deceuninck et al. (2015) [70] investigated the presence of a large group of BPA analogues in breast milk samples $(N=30)$ and detected BPS in one sample at a 0.23 $\mu \mathrm{g} / \mathrm{kg}$ concentration, whereas the rest of the BPA analogues investigated were not detected. In a study by Niu et al. (2017) [22] also on human breast milk from Chinese mothers, BPF, BPS, and BPAF were found, where BPA was still the most frequently compound detected, followed by BPF. This is the first study reporting on the presence of BPF and BPAF in human breast milk.

Available studies on BPF and BPS quantification in other biological matrices are still limited. The detection frequency of these compounds in human serum is relatively low [71]. BPS has been found in maternal and cord blood serum [33]. More recently, Song et al. (2019) [72] found a detection frequency of more than $65 \%$ for BPA, BPAF, and BPF in serum samples collected from residents living near recycling facilities where e-waste was being dismantled, with GM concentrations of 3.2, 0.0074, and $0.062 \mu \mathrm{g} / \mathrm{mL}$, respectively.

The presence of BPA analogues in human biological samples suggests that it may have an effect on the body. The estrogen activity is the most widely studied effect of BPA, and its effects on other hormonal receptors have also been reported [65]. However, limited studies have reported that BPA analogues have endocrine-disrupting activities similar to those of BPA [17]. The estrogenicity of BPs was first reported in 1998 using an E-SCREEN assay in cultures of the human breast cancer cell line MCF7 [73]. Later on, in 2002, we demonstrated the effects of these chemicals on the expression of estrogen-controlled genes by measuring the induction of pS2 (mRNA and protein) and progesterone receptor as well as the expression of a luciferase reporter gene transfected into MVLN cells [27]. Subsequent studies have corroborated these findings [21]. It has also been reported that the estrogenic effect of some BPs is higher than that of BPA [74]. For example, BPS shows higher hormonal activity, 
which can likely be attributed to its strong polarity and the presence of a sulfonyl group [39,75] and its heat stability and resistance to light $[10,70]$. Moreover, BPS and BPF have been shown to be involved in breast cancer progression as much as BPA by inducing proliferation and migration of MCF-7 clonal cells [76]. Recently, Van Leeuwen et al., (2019) [77] reported that most BPA analogues in in vitro studies have similar or higher estrogenic activity than BPA as well as higher antiandrogenic properties. Other BPA analogues showed both antiestrogenic and antiandrogenic activity.

BPS and BPF are the most studied bisphenol analogues. A systematic review [28] that included 32 studies ( 25 in vitro and 7 in vivo) revealed that the potency of BPF and BPS was in the same order of magnitude as BPA and had similar hormonal effects. Additionally, the review showed that BPS and BPF had hormonal effects beyond those of BPA, such as changes in organ weights and enzyme expression levels. The authors concluded that BPS and BPF seemed to have similar potency and mechanisms of action to those of BPA, posing similar health effects. Other authors have also reported on the similarity between BPS and BPF and BPA in terms of their toxicological profiles, including metabolic, carcinogenic, and reproductive effects, as well as oxidative stress and DNA damage [18,28,78-80].

Some studies in animal models have also suggested the adverse reproductive effects secondary to exposure to BPA analogues, such as reduced sperm and oocyte quality and conversion of cholesterol into biologically active steroid hormones (steroidogenesis). These adverse effects depend on the duration of the exposure and the species investigated [81]. In this context, the effect of long-term BPF exposure on the reproductive neuroendocrine system in zebrafish has been recently demonstrated [82]. Similarly, in the same animal model, BPS was shown to decrease gonad weight and alter plasma estrogen and testosterone, as well as to reduce egg production and hatchability, with longer hatch periods, and increase embryo malformations. Shi et al., (2018) [83] showed that prenatal exposure to BPA analogues with physiologically relevant doses affects male reproductive functions probably due to a spermatogenic defect in the developing testis. Ullah et al. (2019) [84] demonstrated the impact of low-dose chronic exposure to BPB, BPF, and BPS on hypothalamo-pituitary-testicular activities in adult rats. The effect on female reproductive functions in mice after prenatal exposure to BPA analogues was recently demonstrated [85]. The authors concluded that prenatal exposure to bisphenols accelerated the onset of puberty, and the mice exhibited fertility problems, abnormal estrous cyclicity, and dysregulated expression of steroidogenic enzymes, especially with lower doses. Kolla et al., (2018) [86] compared the BPA and BPS exposure effect during the perinatal period on female mouse mammary gland development. The study revealed age- and dose-specific effects of BPS that were different from the effects of BPA. In addition, Zhou (2018) [87] evaluated low-concentration BPS toxicity using L1 larvae of the model animal Caenorhabditis elegans. Multiple indicators at the physiological, biochemical, and molecular levels were tested. Compared with the effects of BPA, the overall results showed that BPS was less noxious, suggesting that individual bisphenols may have unique effects. Other studies have also demonstrated the estrogenic, androgenic, and thyroidogenic activities of BPF and BPS [28,71].

Eladak et al., (2015) [30] developed a fetal testis assay to demonstrate that $10 \mathrm{nmol} / \mathrm{L}$ BPS and $\mathrm{BPF}$ can reduce the basal testosterone secretion by fetal human and mouse testes. Furthermore, more recently, Desdoits-Lethimonier et al., (2017) [88] showed that, using an ex vivo culture system, BPE, BPF, $\mathrm{BPB}$, and $\mathrm{BADGE}$ exhibited antiandrogenic properties in adult human testes. In addition, in a study conducted on GH3 rat cell line, BPA, BPAF, BPB, BPF, BPS, and bisphenol Z (BPZ) have been found to alter the activity of the thyroid endocrine system, which seems to be increased by $17 \beta$-estradiol [89].

Table 2 summarizes the studies reporting on the hormonal effects of BPs. 
Table 2. Studies about hormonal effects of BPs.

\begin{tabular}{|c|c|c|c|c|c|}
\hline Reference & Species Strain Mode & Dose Exposure & Exposure Route & Outcomes & Conclusion \\
\hline $\begin{array}{l}\text { Desdoits-Lethimonier } \\
\text { et al., } 2017 \text { [88] }\end{array}$ & Human & $\begin{array}{l}1^{-9} \text { to } 10^{-5} \mathrm{M} \text { for } 24 \text { or } 48 \mathrm{~h} \text { (BPA, } \\
\text { BPF, BFS, BFE, BPB, and BADGE) }\end{array}$ & $\begin{array}{l}\text { In vitro adult testes from } \\
\text { prostate cancer patients }\end{array}$ & $\begin{array}{l}\text { Significant dose-dependent inhibition between testosterone } \\
\text { levels in the culture medium and concentrations of BPA and } \\
\text { analogues. BPA and analogues induced inhibition of } \\
\text { testosterone production with variations based on duration of } \\
\text { exposure and BPA/analogue concentrations. Germ cells were } \\
\text { not affected by BPA and analogues. }\end{array}$ & $\begin{array}{l}\text { Direct exposure to BPA or its analogues can } \\
\text { result in endocrine alteration in adult } \\
\text { human testes. }\end{array}$ \\
\hline Eladak et al., 2015 [90] & Mouse, human & $\begin{array}{l}\text { 10, 100, 1000, and } 10,000 \mu \mathrm{mol} / \mathrm{L} \\
\text { (BPA, BPF, and BPS) for } 48 \mathrm{~h}\end{array}$ & $\begin{array}{l}\text { In vitro human fetal testes, } \\
\text { in vitro mouse fetal testes }\end{array}$ & $\begin{array}{l}\text { BPS or BPF reduced basal testosterone secretion. BPS or BPF } \\
\text { decreased Insl3 expression. }\end{array}$ & $\begin{array}{l}\text { BPS and BPF result in adverse effects on } \\
\text { testes of mice and humans. }\end{array}$ \\
\hline Kim et al., 2017 [76] & Human & $\begin{array}{c}10^{-9} \text { to } 10^{-5} \mathrm{~mol} / \mathrm{L}(\mathrm{BPA}, \mathrm{BPF} \text {, and } \\
\mathrm{BFS} \text { ) for } 24 \mathrm{~h}\end{array}$ & $\begin{array}{l}\text { In vitro human breast cancer } \\
\text { cells }\end{array}$ & $\begin{array}{l}\text { BPA, BPS, and BPF increased proliferation of MCF-7 CV cell } \\
\text { line by regulating the protein expression of cell cycle-related } \\
\text { genes and epithelial mesenchymal transition (EMT) markers } \\
\text { via the ER-dependent pathway. }\end{array}$ & $\begin{array}{l}\text { BPS and BPF are associated with the } \\
\text { increased risk of breast cancer progression as } \\
\text { much as BPA in the proliferation and } \\
\text { migration of MCF-7 CV cells. }\end{array}$ \\
\hline Mokra et al., 2018 [91] & Human & $\begin{array}{l}0.01,0.1 \text {, and } 1 \mu \mathrm{g} / \mathrm{mL} \\
\text { for } 4 \mathrm{~h}(\mathrm{BPA}, \mathrm{BPS}, \mathrm{BPF}, \text { and BPAF) } \\
0.001,0.01, \text { and } 0.1 \mu \mathrm{g} / \mathrm{mL} \text { for } 48 \mathrm{~h} \\
\text { (BPA, BPS, BPF, and BPAF) }\end{array}$ & $\begin{array}{l}\text { In vitro peripheral blood } \\
\text { mononuclear cells (PBMCs) }\end{array}$ & $\begin{array}{l}\text { After } 48 \mathrm{~h} \text {, damage was present and change in PBMCs } \\
\text { (peripheral blood mononuclear cell) viability exposed to BPA, } \\
\text { BPS, BPF, and BPAF for } 48 \mathrm{~h} \text { (from } 0.001 \text { to } 0.1 \mu \mathrm{g} / \mathrm{mL} \text { for } \\
\text { which a decrease in cell viability did not exceed } 20 \% \text { ). }\end{array}$ & $\begin{array}{l}\text { BPA, BPS, BPF, but mostly BPAF, caused } \\
\text { oxidative damage to DNA in pyrimidine } \\
\text { bases and more strongly to purine bases in } \\
\text { human PBMCs. Confirmation of BPA and } \\
\text { BPA analogues being strongly genotoxic. }\end{array}$ \\
\hline $\begin{array}{l}\text { Molina-Molina et al., } \\
2013 \text { [92] }\end{array}$ & Human & $\begin{array}{l}0.01 \text { to } 10 \mu \mathrm{M}(\mathrm{BPA}, \mathrm{BPS} \text {, and BPF) } \\
\text { for } 4 \mathrm{~h}\end{array}$ & $\begin{array}{l}\text { In vitro cells from } \\
\text { leukocyte-buffy coat }\end{array}$ & $\begin{array}{l}\text { BPS, BPF, and BPA activated estrogen receptors. BPS was } \\
\text { more active in the estrogen receptor beta. BPF and BPA were } \\
\text { full androgen receptor agonist. }\end{array}$ & $\begin{array}{l}\text { BPA and its analogues affect non-genomic } \\
\text { signaling in estrogen-responsive cells, with } \\
\text { potential consequences for cell function. }\end{array}$ \\
\hline Naderi et al., 2014 [93] & Zebrafish & $\begin{array}{c}0,0.1,1,10 \text {, and } 100 \mu \mathrm{g} / \mathrm{L} \text { for } \\
75 \text { days (BPS) }\end{array}$ & In vivo embryos & $\begin{array}{l}\text { Gonadosomatic index was reduced }(\geq 10 \mu \mathrm{g} / \mathrm{L}) \text { and } \\
\text { hepatosomatic index increased. Plasma } 17 \beta \text {-estradiol levels } \\
(\geq 1 \mu \mathrm{g} / \mathrm{L}) \text { were increased and testosterone showed a } \\
\text { reduction in males }(10 \text { and } 100 \mu \mathrm{g} / \mathrm{L}) \text {. An induction in plasma } \\
\text { vitolegenin level was observed }(\geq 10 \mu \mathrm{g} / \mathrm{L}) \text {. Egg production } \\
\text { and sperm count were decreased }(10 \text { and } 100 \mu \mathrm{g} / \mathrm{L}) \text {. } \\
\text { Postponed and decreased rates of hatching were observed. }\end{array}$ & $\begin{array}{l}\text { Exposure to low doses of BPS has adverse } \\
\text { effects on different parts of the endocrine } \\
\text { system in zebrafish. }\end{array}$ \\
\hline Roelofs et al., 2015 [79] & Mouse & $\begin{array}{c}10 \text { to } 300 \mu \mathrm{M} \text { (BPA) for } 48 \mathrm{~h} \\
0.01 \text { to } 100 \mu \mathrm{M} \text { (BPF) for } 48 \mathrm{~h} \\
10 \mu \mathrm{M} \text { (BPS) for } 48 \mathrm{~h} \\
10 \text { to } 100 \mu \mathrm{M} \text { (TBBPA) for } 48 \mathrm{~h}\end{array}$ & In vitro Leydig cell line $\mathrm{M}^{-10}$ & $\begin{array}{l}\text { BPA and BPF presented glucocorticoid receptor (GR) and } \\
\text { androgen receptor (AR) antagonism with IC } \mathrm{IC}_{50} \text { values of } 67 \\
\mu \mathrm{M}, 60 \mu \mathrm{M} \text {, and } 22 \mathrm{nM} \text { for GR, and } 39 \mu \mathrm{M}, 20 \mu \mathrm{M} \text {, and } 982 \\
\mathrm{nM} \text { for AR, respectively, whereas BPS did not affect receptor } \\
\text { activity. Testicular steroidogenesis was altered by all BPs } \\
\text { tested. BPF and BPS increased the levels of progestogens that } \\
\text { are formed in the beginning of the steroidogenic pathway. }\end{array}$ & $\begin{array}{l}\text { BPF and BPS induce Leydig cell testosterone } \\
\text { secretion and GR antagonism in the } \\
\text { nanomolar range. }\end{array}$ \\
\hline $\begin{array}{l}\text { Rosenmai et al., } 2014 \\
{[78]}\end{array}$ & Human & $\begin{array}{l}0.3 \text { to } 100 \mu \mathrm{M} \text { (BPA, BPB, BPE, BPF, } \\
\text { BPS, and BPP) for } 24 \mathrm{~h}\end{array}$ & $\begin{array}{l}\text { In vitro adrenal } \\
\text { cortico-carcinoma cells }\end{array}$ & $\begin{array}{l}\text { BPS presented less estrogenic and antiandrogenic activity } \\
\text { than BPA. BPS showed the largest efficacy } \\
\text { on17 } \alpha \text {-hydroxyprogesterone. }\end{array}$ & $\begin{array}{l}\text { BPA analogues interfere with the } \\
\text { endocrine system. }\end{array}$ \\
\hline $\begin{array}{l}\text { Stroheker et al., } 2003 \\
{[\text { [94] }}\end{array}$ & Rat & $\begin{array}{c}0,25,50,100 \text {, and } 200 \mathrm{mg} / \mathrm{kg} \\
\text { bw/day (BPA and BPF) for } 21 \text { days }\end{array}$ & In vivo system & $\begin{array}{l}\text { BPA did not induce an increase in relative wet or dry uterine } \\
\text { weight. BPF induced a significant dose-related increase in } \\
\text { relative wet uterine weight at } 100 \mathrm{mg} / \mathrm{kg} \text { bw/day and above } \\
\text { and a significant increase of relative dry uterine weight at } \\
200 \mathrm{mg} / \mathrm{kg} \text { bw/day. }\end{array}$ & $\begin{array}{l}\text { Exposure to BPF has weak estrogenic effects } \\
\text { in rats. In immature rats, the effects are more } \\
\text { sensitive, inducing uterine growth. }\end{array}$ \\
\hline
\end{tabular}




\section{Obesogenic Effects of Bisphenol A Analogues}

There is increasing evidence that a number of chemicals can interfere in hormonal metabolism and regulation of adipocyte function. This may result in imbalanced hormone levels, which can lead to obesity. These obesity-promoting compounds are known as "obesogens" [95].

It seems that genetic predisposition, unhealthy dietary habits as well as a sedentary lifestyle alone are not responsible for the global epidemic of overweightedness and obesity [95].

At a molecular level, another mechanism by which obesogens could lead to weight gain or obesity is through the activation of nuclear transcription factors, such as the peroxisome proliferator-activated receptors alpha, delta, and gamma (PPAR $\alpha, \operatorname{PPAR}-\delta$, and PPAR- $\gamma$ ) and steroid hormone receptors, that regulate adipocyte proliferation and differentiation and lipid metabolism, thereby influencing body composition. The transcription factors bind to response elements in the DNA-regulating specific patterns of gene expression [95]. Wassenaar et al., (2017) [96] conducted a systematic review of the literature and found a significant positive association between early-life exposure to BPA and fat weight and triglycerides.

BPA promotes adipogenesis, adipose tissue inflammation, and alteration of glucose and lipid metabolism [97]. BPA has the ability to bind to human and animal PPAR $\gamma$, which could trigger obesogenic activities [98]. PPAR $\gamma$ is highly expressed in adipose tissue and regulates adipocyte development and the uptake of lipids by adipocytes. Obesogens can cause obesity through direct activation of PPAR $\gamma$, but other mechanisms involve indirect activation of the receptor by increasing the PPAR $\gamma$ protein and making it available to promoters of genes in the adipogenic pathway [99]. Measurements of the effects of BPA exposure on obesity should consider not only the body mass index (BMI) but also the role of BPA in adipogenesis, lipid, and glucose dysregulation and the presence of adipose tissue inflammation, which in turn results from the increased secretion of proinflammatory compounds [97].

As with the hormonal effects of BPA substitutes, their obesogenic activity has not been well studied. However, the ability of BPS to promote accumulation of lipids and differentiation of human preadipocytes through the activation of a PPAR $\gamma$ pathway has been described [100]. Damage in the transcriptome of preadipocytes during their differentiation has been described in relation to long-term exposure to low doses of BPA or BPS and BPF [101]. As with BPA, BPS could induce differentiation of preadipocytes. Both BPA and BPS are weak activators of PPAR $\gamma$ and need this receptor to induce adipogenesis [102]. BPA and BPS can increase the differentiation of 3T3-L1 preadipocytes in mice in a dose-dependent manner. Moreover, BPS has shown stronger adipogenic activity than BPA [102].

Ivry Del Moral et al., (2016) [103] showed that BPS can increase the harmful effects of a high-fat diet and induce changes in the postprandial lipid metabolism, increasing fat accumulation in the adipose tissue.

Recently, Charisiadis et al., (2018) [104] investigated the relation between obesity and the presence of BPA and BPF in hypothalamic and white matter postmortem material from 12 pairs of obese (BMI $\left.>30 \mathrm{~kg} / \mathrm{m}^{2}\right)$ and normal-weight individuals. A significant association $(p<0.05)$ between BPA and BPF concentration and obesity was found, except for BPF in white matter samples.

In another study by Liu et al. (2017) [33] conducted in 1521 adults ( $\geq 20$ years) who participated in the National Health and Nutrition Examination Survey 2013-2014, significant associations were found between BPA exposure and general and abdominal obesity, whereas no significant associations were found for BPF or BPS, at the current exposure level. However, the authors suggested continued biomonitoring of these BPA substitutes.

In addition, a recent study by Liu et al., (2019) [62] showed for the first time that exposure to BPF was positively associated with a higher risk of obesity in children and adolescents. This association was mainly found in boys, suggesting a potential gender influence.

Table 3 summarizes the studies reporting on the obesogenic effect of BPs. 
Table 3. Studies about obesogenic effects of BPs.

\begin{tabular}{|c|c|c|c|c|c|}
\hline Reference & Species Strain Model & Dose Exposure Period & Exposure Route & Outcomes & Conclusion \\
\hline $\begin{array}{l}\text { Ahmed and Atlas, } 2016 \\
\text { [102] }\end{array}$ & Mouse & $\begin{array}{c}0.01-50 \mu \mathrm{M}(\mathrm{BPS}) \text { and } 0.01-50 \mu \mathrm{M} \\
\text { (BPA) for } 2 \text { days }\end{array}$ & In vitro 3T3-L1 cells & $\begin{array}{l}\text { BPS promotes the expression of adipogenic markers and } \\
\text { lipid storage. Treatment of 3T3-L1 cells with BPS can } \\
\text { increase lipoprotein lipase, adipocyte protein 2, PPAR } \gamma \\
\text { (Peroxisome proliferator-activated receptor), perilipin, } \\
\text { adipsin, and enhancer-binding protein alpha mRNA } \\
\text { expression levels. BPS and BPA can weakly activate } \\
\text { PPAR } \gamma \text { using a PPAR } \gamma \text {. BPS but not BPA was able to } \\
\text { competitively inhibit rosiglitazone activated PPAR } \gamma .\end{array}$ & $\begin{array}{l}\text { BPS is a more potent adipogen than BPA. } \\
\text { BPA and BPS can upgrade 3T3-L1 adipocyte } \\
\text { differentiation in a dose-dependent manner } \\
\text { and require PPAR } \gamma \text { to adipogenesis. }\end{array}$ \\
\hline Boucher et al., 2016 [100] & Human & $0.1 \mathrm{nM}$ to $25 \mu \mathrm{M}$ (BPS) for 14 days & $\begin{array}{l}\text { In vitro primary } \\
\text { preadipocytes }\end{array}$ & $\begin{array}{l}25 \mu \mathrm{M} \text { BPS induced lipid accumulation, increased the } \\
\text { mRNA and protein levels of several adipogenic markers, } \\
\text { including lipoprotein lipase and adipocyte protein2 }(\mathrm{aP2}) \text {. } \\
\text { BPS did not affect lipoprotein lipase protein levels. }\end{array}$ & $\begin{array}{l}\text { BPS promotes lipid storage and } \\
\text { differentiation of primary human } \\
\text { preadipocyte. }\end{array}$ \\
\hline $\begin{array}{l}\text { Ivry Del Moral et al., } 2016 \\
\text { [103] }\end{array}$ & Mouse & $\begin{array}{c}0.2,1.5,50 \mu \mathrm{\mu g} / \mathrm{kg} \mathrm{bw} / \mathrm{day} \text { (BPS) for } \\
23 \text { weeks }\end{array}$ & In vivo system & $\begin{array}{l}\text { BPs induced overweightedness in male mice offspring fed } \\
\text { with a high-fat diet at the two highest doses of BPs. } \\
\text { Obesity was related to hyperinsulinemia, } \\
\text { hyperleptinemia, and fat mass. Plasma triglycerides were } \\
\text { significantly increased with BPs. Finally, BPS induced } \\
\text { alteration in mRNA expression of marker genes involved } \\
\text { in adipose tissue homeostasis. }\end{array}$ & $\begin{array}{l}\text { BPS potentiates obesity in high-fat diets by } \\
\text { inducing lipid storage linked to faster lipid } \\
\text { plasma clearance. }\end{array}$ \\
\hline Liu et al., 2017 [33] & Human & $\begin{array}{c}\text { Median urinary concentrations were: } \\
-0.7 \text { to } 1.47 \mathrm{ng} / \mathrm{L} \text { BPA } \\
-0.1 \text { to } 1.3 \mathrm{ng} / \mathrm{LBPF} \\
-0.2 \text { to } 1.0 \mathrm{ng} / \mathrm{L} \mathrm{BPS}\end{array}$ & Human urine & $\begin{array}{l}\text { Associations between BPA levels and obesity were } \\
\text { stronger in men (OR }=2.10 ; 95 \% \text { CI: } 1.20-3.68) \text { than in } \\
\text { women and for white }(\mathrm{OR}=2.41 ; 95 \% \text { CI: } 1.32-4.43) \text { than } \\
\text { non-white participants. The associations of BPS and BPF } \\
\text { with general obesity did not differ by sex or ethnicity. }\end{array}$ & $\begin{array}{l}\text { There was association of BPA exposure with } \\
\text { general obesity and abdominal obesity. }\end{array}$ \\
\hline Riu et al., 2011 [98] & $\begin{array}{l}\text { Human, zebrafish, } \\
\text { Xenopus }\end{array}$ & $\begin{array}{c}10^{-9} \text { to } 10^{-4} \mathrm{M} \text { (BPA, TetrabromoBPA } \\
\text { and tetrachloroBPA) }\end{array}$ & $\begin{array}{l}\text { In vitro estrogen receptors } \\
\text { (ERs) and PPARs }\end{array}$ & $\begin{array}{l}\text { TetrabromoBPA and tetrachloroBPA are human, zebrafish, } \\
\text { and Xenopus PPAR } \gamma \text { ligands and determine the } \\
\text { mechanism by which these chemicals bind to an activated } \\
\text { PPAR } \gamma \text {. Activation of ER } \alpha \text {, ER } \beta \text {, and PPAR } \gamma \text { depends on } \\
\text { the degree of halogenation in BPA analogues. Bulkier } \\
\text { brominated BPA analogues have a greater capability to } \\
\text { activate PPAR } \gamma \text { and a weaker estrogenic potential. }\end{array}$ & $\begin{array}{l}\text { Polyhalogenated BPs could function as } \\
\text { obesogens acting as agonists to disrupt } \\
\text { physiological functions regulated by human } \\
\text { or animal PPAR } \gamma \text {. }\end{array}$ \\
\hline Verbanck et al., 2017 [101] & Human & $\begin{array}{l}10 \mathrm{nM} \text { and } 10 \mu \mathrm{M} \text { (BPA, BPS, and } \\
\text { BPF) for } 10 \text { days }\end{array}$ & $\begin{array}{l}\text { In vitro primary } \\
\text { preadipocytes from } \\
\text { subcutaneous fats }\end{array}$ & $\begin{array}{l}\text { Chronic exposure of preadipocytes to BPA, or its } \\
\text { substitutes BPS and BPF, results in deleterious effects on } \\
\text { their transcriptome during differentiation of human } \\
\text { primary adipocytes, even at a low dose }(10 \mathrm{nM}) \text {. }\end{array}$ & $\begin{array}{l}\text { Caution required over the use of BPA, BPS, } \\
\text { and BPF, since unsuspected cell damage } \\
\text { could be initiated at low doses. }\end{array}$ \\
\hline
\end{tabular}




\section{Conclusions}

Given the similarities between BPA and BPA analogues in terms of their metabolism and actions, including hormonal effects beyond those of BPA, it is little surprise that these substitutes also represent a risk to wildlife and human health. Regulations on the assessment of the safety of consumer products should be extended to cover all the compounds of the same chemical group. In addition, as recommended by different researchers, more efforts are needed to find chemical substitutes without hazardous health effects. The substitution trend toward BPA analogues in consumer products, particularly in food contact materials, should be implemented with caution and include effective and regular monitoring to assess their effects on human health.

Author Contributions: Conceptualization, A.Z.-G. and C.M. Methodology, all authors; Data Curation, N.A. and Y.G.-Z.; Writing-Original Draft Preparation, M.A., A.R., and C.M.; Writing-Review and Editing, M.J.A.-C. and L.R.; Visualization, M.A.; Supervision, A.R. and A.Z.-C.; Project Administration, A.R.; Funding Acquisition, A.R. All authors revised and approved the manuscript.

Funding: This research received no external funding.

Acknowledgments: This research was funded by Plan Estatal de I+D+I 2013-2016 Proyecto cofinanciado FEDER-ISCIII PI17/01758 and by Fundación Mapfre MAPFRE2018.

Conflicts of Interest: The authors declare no conflict of interest.

\section{Abbreviations}

$\begin{array}{ll}\text { BPA } & \text { Bisphenol A } \\ \text { BPS } & \text { Bisphenol S } \\ \text { BPF } & \text { Bisphenol F } \\ \text { BPB } & \text { Bisphenol B } \\ \text { BPE } & \text { Bisphenol E } \\ \text { BPAF } & \text { Bisphenol AF } \\ \text { BPs } & \text { Bisphenols analogues } \\ \text { BPP } & \text { Bisphenol P } \\ \text { BPZ } & \text { Bisphenol Z } \\ \text { BADGE } & \text { Bisphenol A diglycidyl ether } \\ \text { BFDGE } & \text { Bisphenol F diglycidyl ether } \\ \text { PPAR } \alpha & \text { Peroxisome proliferator-activated receptor alfa } \\ \text { PPAR } \delta & \text { Peroxisome proliferator-activated receptor delta } \\ \text { PPAR } \gamma & \text { Peroxisome proliferator-activated receptor gamma }\end{array}$

\section{References}

1. Kabir, E.R.; Rahman, M.S.; Rahman, I. A review on endocrine disruptors and their possible impacts on human health. Environ. Toxicol. Pharmacol. 2015, 40, 241-258. [CrossRef]

2. Anifandis, G.; Amiridis, G.; Dafopoulos, K.; Daponte, A.; Dovolou, E.; Gavriil, E.; Gorgogietas, V.; Kachpani, E.; Mamuris, Z.; Messini, C.I.; et al. The in Vitro Impact of the Herbicide Roundup on Human Sperm Motility and Sperm Mitochondria. Toxics 2018, 6, 2. [CrossRef]

3. Anifandis, G.; Katsanaki, K.; Lagodonti, G.; Messini, C.; Simopoulou, M.; Dafopoulos, K.; Daponte, A. The Effect of Glyphosate on Human Sperm Motility and Sperm DNA Fragmentation. Int. J. Environ. Res. Public Health 2018, 15, 1117. [CrossRef]

4. Kang, J.H.; Kondo, F.; Katayama, Y. Human exposure to bisphenol A. Toxicology 2006, 226, 79-89. [CrossRef]

5. Cacho, J.I.; Campillo, N.; Viñas, P.; Hernández-Córdoba, M. Stir Bar Sorptive Extraction Coupled to Gas Chromatography-Mass Spectrometry for the Determination of Bisphenols in Canned Beverages and Filling Liquids of Canned Vegetables. J. Chromatogr. A 2012, 1247, 146-153. [CrossRef]

6. García, J.A.; Gallego, C.; Font, G. Toxicidad del Bisfenol A: Revisión. Rev. Toxicol. 2015, 32, 144-160.

7. Chen, M.Y.; Ike, M.; Fujita, M. Acute toxicity, mutagenicity, and estrogenicity of bisphenol A and other bisphenols. Environ. Toxicol. Int. J. 2002, 17, 80-86. [CrossRef] 
8. Regueiro, J.; Breidbach, A.; Wenzl, T. Derivatization of bisphenol A and its analogues with pyridine-3-sulfonyl chloride: Multivariate optimization and fragmentation patterns by liquid chromatography/Orbitrap mass spectrometry. Rapid Commun. Mass Spectrom. 2015, 29, 1473-1484. [CrossRef]

9. Regueiro, J.; Wenzl, T. Determination of bisphenols in beverages by mixed-mode solid-phase extraction and liquid chromatography coupled to tandem mass spectrometry. J. Chromatogr. A 2015, 1422, 230-238. [CrossRef]

10. García-Córcoles, M.T.; Cipa, M.; Rivas, A.; Olea-Serrano, F.; Vílchez, A.J.; Zafra-Gómez, A. Determination of Bisphenols with Estrogenic Activity in Plastic Packaged Baby Food Samples Using Solid-Liquid Extraction and Clean-up with Dispersive Sorbents Followed by Gas Chromatography Tandem Mass Spectrometry. Talanta 2018, 178, 441-448. [CrossRef]

11. Rochester, J.R. Bisphenol A and human health: A review of the literature. Reprod. Toxicol. 2013, 42, $132-155$. [CrossRef]

12. Barroso, J.M. European Commission Directive 2011/8/EU of 28 January 2011 amending directive 2002/72/EC as regards the restriction of use of bisphenol A in plastic infant feeding bottles. Off. J. Eur. Union 2011, 26, 11-14.

13. European Commission. Commission Regulation (EU) 2018/213 on the use of bisphenol A in varnishes and coatings intended to come into contact with food and amending Regulation No 10/2011 as regards the use of that substance in plastic food. 2018. Available online: http://data.europa.eu/eli/reg/2018/213/oj (accessed on 31 August 2019).

14. French Republic, Regulation No. 1442/2012 of 24 December 2012 Aiming at Banning the Manufacture, Import, Export and Commercialisation of All Forms of Food Packaging Containing Bisphenol A. Off. J. French Republic 2012. Available online: https://www.legifrance.gouv.fr/jo_pdf.do?numJO=0\&dateJO=20121226\&numTexte= 2\&pageDebut=20395\&pageFin=20396 (accessed on 31 August 2019).

15. Food and Drug Administration (FDA). Indirect Food Additives: Polymers; Federal Register: Rockville, MD, USA, 2012; Volume 77, pp. 41899-41902.

16. Food and Drug Administration (FDA). Indirect Food Additives: Adhesives and Components of Coatings; Federal Register: Rockville, MD, USA, 2013; Volume 78, pp. 41840-41843.

17. Liao, C.; Liu, F.; Kannan, K.; Bisphenol, S. A new bisphenol analogue, in paper products and currency bills and its association with bisphenol A residues. Environ. Sci. Technol. 2012, 46, 6515-6522. [CrossRef]

18. Gallo, P.; Pisciottano, I.D.M.; Esposito, F.; Fasano, E.; Scognamiglio, G.; Mita, G.D.; Cirillo, T. Determination of BPA, BPB, BPF, BADGE and BFDGE in Canned Energy Drinks by Molecularly Imprinted Polymer Cleaning up and UPLC with Fluorescence Detection. Food Chem. 2017, 220, 406-412. [CrossRef]

19. Kitamura, S.; Suzuki, T.; Sanoh, S.; Kohta, R.; Jinno, N.; Sugihara, K. Comparative study of the endocrine-disrupting activity of bisphenol A and 19 related compounds. Toxicol. Sci. 2005, 84, 249-259. [CrossRef]

20. Feng, Y.; Yin, J.; Jiao, Z.; Shi, J.; Li, M.; Shao, B. Bisphenol AF may cause testosterone reduction by directly affecting testis function in adult male rats. Toxicol. Lett. 2012, 211, 201-209. [CrossRef]

21. Chen, D.; Kannan, K.; Tan, H.; Zheng, Z.; Feng, Y.L.; Wu, Y.; Widelka, M. Bisphenol analogues other than BPA: Environmental occurrence, human exposure, and toxicity: A review. Environ. Sci. Technol. 2012, 50, 5438-5453. [CrossRef]

22. Niu, Y.; Wang, B.; Zhao, Y.; Zhang, J.; Shao, B. Highly sensitive and high-throughput method for the analysis of bisphenol analogues and their halogenated derivatives in breast milk. J. Agric. Food Chem. 2017, 65, 10452-10463. [CrossRef]

23. Liao, C.; Liu, F.; Alomirah, H.; Loi, V.D.; Mohd, M.A.; Moon, H.B.; Nakata, H.; Kannan, K. Bisphenol S in urine from the United States and seven Asian countries: Occurrence and human exposures. Environ. Sci. Technol. 2012, 46, 6860-6866. [CrossRef]

24. Kojima, H.; Takeuchi, S.; Sanoh, S.; Okuda, K.; Kitamura, S.; Uramaru, N.; Sugihara, K.; Yoshinari, K. Profiling of bisphenol A and eight its analogues on transcriptional activity via human nuclear receptors. Toxicology 2019, 413, 48-55. [CrossRef]

25. Pelch, K.; Wignall, J.A.; Goldstone, A.E.; Ross, P.K.; Blain, R.B.; Shapiro, A.J.; Holmgren, S.D.; Hsieh, J.H.; Svoboda, D.; Auerbach, S.S.; et al. A scoping review of the health and toxicological activity of bisphenol A (BPA) structural analogues and functional alternatives. Toxicology 2019, 424, 152235. [CrossRef] 
26. Punt, A.; Aartse, A.; Bovee, T.F.H.; Gerssen, A.; Van Leeuwen, S.P.J. Hoogenboom RLAP, Peijnenburg AACM. Quantitative in vitro-to-in vivo extrapolation (QIVIVE) of estrogenic and anti-androgenic potencies of BPA and BADGE analogues. Arch. Toxicol. 2019, 93, 1941-1953. [CrossRef]

27. Rivas, A.; Lacroix, M.; Olea-Serrano, F.; Laos, I.; Leclercq, G.; Olea, N. Estrogenic effect of a series of bisphenol analogues on gene and protein expression in MCF-7 breast cancer cells. J. Steroid Biochem. Mol. Biol. 2002, 82, 45-53. [CrossRef]

28. Rochester, J.R.; Bolden, A.L. Bisphenol S and F: A systematic review and comparison of the hormonal activity of bisphenol A substitutes. Environ. Health Perspect. 2015, 123, 643-650. [CrossRef]

29. Gallart-Ayala, H.; Moyano, E.; Galceran, M.T. Fast liquid chromatographytandem mass spectrometry for the analysis of bisphenol A-diglycidyl ether, bisphenol F-diglycidyl ether and their derivatives in canned food and beverages. J. Chromatogr. A 1218, 2011, 1603-1610.

30. Eladak, S.; Grisin, T.; Moison, D.; Guerquin, M.J.; N’Tumba-Byn, T.; Pozzi-Gaudin, S.; Benachi, A.; Livera, G.; Rouiller-Fabre, V.; Habert, R. A new chapter in the bisphenol a story: Bisphenol S and bisphenol F are not safe alternatives to this compound. Fertil. Steril. 2015, 103, 11-21. [CrossRef]

31. Chin, K.Y.; Pang, K.L.; Mark-Lee, W.F. A Review on the Effects of Bisphenol A and Its Derivatives on Skeletal Health. Int. J. Med. Sci. 2018, 15, 1043-1050. [CrossRef]

32. Ješeta, M.; Crha, T.; Žáková, J.; Ventruba, P. Bisphenols in the pathology of reproduction. Ceska Gynekol. 2019, 84, 161-165.

33. Liu, B.; Lehmler, H.J.; Sun, Y.; Xu, G.; Liu, Y.; Zong, G.; Sun, Q.; Hu, F.B.; Wallace, R.B.; Bao, W. Bisphenol A substitutes and obesity in US adults: Analysis of a population-based, cross-sectional study. Lancet Planet. Health 2017, 1, e114-e122. [CrossRef]

34. Ferguson, K.K.; Lan, Z.; Yu, Y.; Mukherjee, B.; McElrath, T.F.; Meeker, J.D. Urinary concentrations of phenols in association with biomarkers of oxidative stress in pregnancy: Assessment of effects independent of phthalates. Environ. Int. 2019, 131, 104903. [CrossRef]

35. Inadera, H. Neurological Effects of Bisphenol A and its Analogues. Int. J. Med. Sci. 2015, 12, 926-936. [CrossRef]

36. Moher, D.; Liberati, A.; Tetzlaff, J.; Altman, D.G. The PRISMA Group. Preferred Reporting Items for Systematic Reviews and Meta-Analyses: The PRISMA Statement. PLoS Med. 2009, 6, e1000097. [CrossRef]

37. Liao, C.; Kannan, K. Concentrations and profiles of bisphenol A and other bisphenol analogues in foodstuffs from the united states and their implications for human exposure. J. Agric. Food Chem. 2013, 61, 4655-4662. [CrossRef]

38. Liao, A.; Kannan, K. A survey of bisphenol A and other bisphenol analogues in foodstuffs from nine cities in China. Food Addit. Contam. Part A Chem. Anal. Control Expo. Risk Assess. 2014, 31, 319-329. [CrossRef]

39. Gallart-Ayala, H.; Moyano, E.; Galceran, M.T. Analysis of bisphenols in soft drinks by on-line solid phase extraction fast liquid chromatography-tandem mass spectrometry. Anal. Chim. Acta 2011, 683, 227-233. [CrossRef]

40. Cesen, M.; Lambropoulou, D.; Laimou-Geraniou, M.; Kosjek, T.; Blanznik, U.; Heath, D.; Heath, E. Determination of Bisphenols and Related Compounds in Honey and Their Migration from Selected Food Contact Materials. J. Agric. Food. Chem. 2016, 64, 8866-8875. [CrossRef]

41. Sadeghi, M.; Nematifar, Z.; Fattahi, N.; Pirsaheb, M.; Shamsipur, M. Determination of Bisphenol A in Food and Environmental Samples Using Combined Solid-Phase Extraction-Dispersive Liquid-Liquid Microextraction with Solidification of Floating Organic Drop Followed by HPLC. Food Anal. Methods 2016, 9, 1814-1824. [CrossRef]

42. Zoller, O.; Brüschweiler, B.J.; Magnin, R.; Reinhard, H.; Rhyn, P.; Rupp, H.; Zeltner, S.; Felleisen, R. Natural occurrence of bisphenol F in mustard. Food Addit. Contam. Part A Chem. Anal. Control Expo. Risk Assess. 2016, 33, 137-146. [CrossRef]

43. Xionga, L.; Yana, P.; Chua, M.; Gaoa, Y.Q.; Lia, W.H.; Yanga, X.L. A rapid and simple HPLC-FLD screening method with QuEChERS as the sample treatment for the simultaneous monitoring of nine bisphenols in milk. Food Chem. 2018, 244, 371-377. [CrossRef]

44. Lane, R.F.; Adams, C.D.; Randtke, S.J.; Carter, R.E. Chlorination and chloramination of bisphenol A, bisphenol F, and bisphenol A diglycidyl ether in drinking water. Water Res. 2015, 79, 68-78. [CrossRef]

45. Abou-Omar, T.; Sukhn, C.; Fares, S.A.; Abiad, M.G.; Habib, R.R.; Dhaini, H.R. Bisphenol A exposure assessment from olive oil consumption. Environ. Monit. Assess. 2017, 189, 341. [CrossRef] 
46. Alabi, A.; Caballero-Casero, N.; Rubio, S. Quick and simple sample treatment for multiresidue analysis of bisphenols, bisphenol diglycidyl ethers and their derivatives in canned food prior to liquid chromatography and fluorescence detection. J. Chromatogr. A 2014, 1336, 23-33. [CrossRef]

47. Cirillo, T.; Latini, G.; Castaldi, M.A.; Dipaola, L.; Fasano, E.; Esposito, F.; Scognamiglio, G.; Di Francesco, F.; Cobellis, L. Exposure to di-2-ethylhexyl phthalate, di-n-butyl phthalate and bisphenol A through infant formulas. J. Agric. Food Chem. 2015, 63, 3303-3310. [CrossRef]

48. Cunha, S.C.; Almeida, C.; Mendes, E.; Fernandes, J.O. Simultaneous determination of bisphenol A and bisphenol B in beverages and powdered infant formula by dispersive liquid-liquid micro-extraction and heart-cutting multidimensional gas chromatography-mass spectrometry. Food Addit. Contam. 2011, 28, 513-526. [CrossRef]

49. Cunha, S.C.; Cunha, C.; Ferreira, A.R.; Fernandes, J.O. Determination of bisphenol A and bisphenol B in canned seafood combining QuEChERS extraction with dispersive liquid-liquid microextraction followed by gas chromatography-mass spectrometry. Anal. Bioanal. Chem. 2012, 404, 2453-2463. [CrossRef]

50. Cunha, S.C.; Fernandes, J.O. Assessment of bisphenol A and bisphenol B in canned vegetables and fruits by gas chromatography mass spectrometry after QuEChERS and dispersive liquid-liquid microextraction. Food Control 2013, 33, 549-555. [CrossRef]

51. Fasano, E.; Esposito, F.; Scognamiglio, G.; Di Francesco, F.; Montuori, P.; Amodio-Cocchieri, R.; Cirillo, T. Bisphenol A contamination in soft drinks as a risk for children's health in Italy. Food Add. Contm. A 2015, 32, 1207-1214. [CrossRef]

52. Feshin, D.B.; Fimushkin, P.V.; Brodskii, E.S.; Shelepchikov, A.A.; Mir-Kadyrova, E.Y.; Kalinkevich, G.A. Determination of bisphenol $\mathrm{A}$ in foods as 2,2-bis-(4-(isopropoxycarbonyloxy) phenyl) propane by gas chromatography/mass spectrometry. J. Anal. Chem. 2012, 67, 460-466. [CrossRef]

53. Grumetto, L.; Gennari, O.; Montesano, D.; Ferracane, R.; Ritieni, A.; Albrizio, S.; Barbato, F. Determination of five bisphenols in commercial milk samples by liquid chromatography coupled to fluorescence detection. J. Food Prot. 2013, 76, 1590-1596. [CrossRef]

54. Kuo, H.W.; Ding, W.H. Trace determination of bisphenol A and phytoestrogens in infant formula powders by gas chromatography-mass spectrometry. J. Chromatogr. A 2004, 1027, 67-74. [CrossRef]

55. Lapviboonsuk, J.; Leepipatpiboon, N. A simple method for the determination of bisphenol A diglycidyl ether and its derivatives in canned fish. Anal. Methods 2014, 6, 5666-5672. [CrossRef]

56. Pardo, O.; Yusa, V.; Leon, N.; Pastor, A. Determination of bisphenol diglycidyl ether residues in canned foods by pressurized liquid extraction and liquid chromatography-tandem mass spectrometry. J. Chromatogr. A 2006, 1107, 70-78. [CrossRef]

57. Rastkari, N.; Ahmadkhaniha, R.; Yunesian, M.; Baleh, L.J.; Mesdaghinia, A. Sensitive determination of bisphenol $\mathrm{A}$ and bisphenol $\mathrm{F}$ in canned food using a solid-phase microextraction fibre coated with single-walled carbon nanotubes before GC/MS. Food Addit. Contam. 2010, 27, 1460-1468. [CrossRef]

58. Rauter, W.; Dickinger, G.; Zihlarz, R.; Lintschinger, J. Determination of bisphenol A diglycidyl ether (BADGE) and its hydrolysis products it canned oily foods from the Austrian market. Z. Leb. Unters. Forsch. A 1999, 208, 208-211. [CrossRef]

59. Simoneau, A.; Van den Eede, L.; Valzacchi, S. Identification and quantification of the migration of chemicals from plastic baby bottles used as substitutes for polycarbonate. Food Addit. Contam. 2012, 29, 469-480. [CrossRef]

60. Viñas, P.; Campillo, N.; Martínez-Castillo, N.; Hernández-Córdoba, M. Comparison of two derivatizationbased methods for solid-phase microextraction-gas chromatography-mass spectrometric determination of bisphenol A, bisphenol S and biphenol migrated from food cans. Anal. Bioanal. Chem. 2010, 397, 115-125. [CrossRef]

61. Yang, Y.; Yu, J.; Yin, J.; Shao, B.; Zhang, J. Molecularly imprinted solid-phase extraction for selective extraction of bisphenol analogues in beverages and canned food. J. Agric. Food Chem. 2014, 62, 11130-11137. [CrossRef]

62. Liu, B.; Lehmler, H.-J.; Sun, Y.; Xu, G.; Sun, Q.; Snetselaar, L.G.; Wallace, R.B.; Bao, W. Association of Bisphenol A and Its Substitutes, Bisphenol F and Bisphenol S, with Obesity in United States Children and Adolescents. Diabetes Metab. J. 2019, 43, 59. [CrossRef]

63. Pottenger, L.H.; Domoradzki, J.Y.; Markham, D.A.; Hansen, S.C.; Cagen, S.Z.; Waechter, J.M., Jr. The Relative Bioavailability and Metabolism of Bisphenol A in Rats Is Dependent upon the Route of Administration. Toxicol. Sci. 2000, 54, 3-18. [CrossRef] 
64. Hanioka, N.; Naito, T.; Narimatsu, S. Human UDP-glucuronosyltransferase isoforms involved in bisphenol A glucuronidation. Chemosphere 2008, 74, 33-36. [CrossRef]

65. Gramec-Skledar, D.; Peterlin-Mašič, L. Bisphenol A and its analogs: Do their metabolites have endocrine activity? Environ. Toxicol. Pharmacol. 2016, 47, 182-199. [CrossRef]

66. Taylor, J.A.; vom Saal, F.S.; Welshons, W.V.; Drury, B.; Rottinghaus, G.; Hunt, P.A.; Toutain, P.-L.; Laffont, C.M.; VandeVoort, C.A. Similarity of bisphenol A pharmacokinetics in rhesus monkeys and mice: Relevance for human exposure. Environ. Health Perspect. 2011, 119, 422-430. [CrossRef]

67. Koch, H.M.; Kolossa-Gehring, M.; Schröter-Kermani, C.; Angerer, J.; Brüning, T. Bisphenol A in 24 h urine and plasma samples of the German Environmental Specimen Bank from 1995 to 2009: A retrospective exposure evaluation. J. Expo. Sci. Environ. Epidemiol. 2012, 22, 610-616. [CrossRef]

68. Ye, X.; Wong, L.-Y.; Kramer, J.; Zhou, X.; Jia, T.; Calafat, A.M. Urinary concentrations of bisphenol A and three other bisphenols in convenience samples of US adults during 2000-2014. Environ. Sci. Technol. 2015, 49, 11834-11839. [CrossRef]

69. Lehmler, H.J.; Liu, B.; Gadogbe, M.; Bao, W. Exposure to Bisphenol A, Bisphenol F, and Bisphenol S in U.S. Adults and Children: The National Health and Nutrition Examination Survey 2013-2014. ACS Omega 2018, 3, 6523-6532. [CrossRef]

70. Deceuninck, Y.; Bichon, E.; Marchand, P.; Boquien, C.Y.; Legrand, A.; Boscher, C.; Antignac, J.P.; Le Bizec, B. Determination of bisphenol A and related substitutes/analogues in human breast milk using gas chromatography-tandem mass spectrometry. Anal. Bioanal. Chem. 2015, 407, 2485-2497. [CrossRef]

71. Thayer, K.A.; Doerge, D.R.; Hunt, D.; Schurman, S.H.; Twaddle, N.C.; Churchwell, M.; Garantziotis, S.; Kissling, G.E.; Easterling, M.R.; Bucher, J.R.; et al. Pharmacokinetics of bisphenol A in humans following a single oral administration. Environ Int. 2015, 83, 107-115. [CrossRef]

72. Song, S.; Duan, Y.; Zhang, T.; Zhang, B.; Zhao, Z.; Bai, X.; Xie, L.; He, Y.; Ouyang, J.P.; Huang, X.; et al. Serum concentrations of bisphenol $\mathrm{A}$ and its alternatives in elderly population living around e-waste recycling facilities in China: Associations with fasting blood glucose. Ecotoxicol. Environ. Saf. 2019, 106, 822-828. [CrossRef]

73. Perez, P.; Pulgar, R.; Olea-Serrano, F.; Villalobos, M.; Rivas, A.; Metzler, M.; Pedraza, V.; Olea, N. The estrogenicity of bisphenol A-related diphenylalkanes with various substituents at the central carbon and the hydroxy groups. Environ. Health Perspect. 1998, 106, 167-174. [CrossRef]

74. Cao, H.; Wang, F.; Liang, Y.; Wang, H.; Zhang, A.; Song, M. Experimental and computational insights on the recognition mechanism between the estrogen receptor $\alpha$ with bisphenol compounds. Arch. Toxicol. 2017, 91, 3897-3912. [CrossRef]

75. Caballero-Casero, N.; Lunar, L.; Rubio, S. Analytical methods for the determination of mixtures of bisphenols and derivatives in human and environmental exposure sources and biological fluids. A review. Anal. Chim. Acta 2016, 908, 22-53. [CrossRef]

76. Kim, J.; Choi, H.; Lee, H.; Lee, G.; Hwang, K.; Choi, K. Effects of bisphenol compounds on the growth and epithelial mesenchymal transition of MCF-7 CV human breast cancer cells. J. Biomed. Res. 2017, 31, 358-369.

77. Van Leeuwen, S.P.; Bovee, T.F.; Awchi, M.; Klijnstra, M.D.; Hamers, A.R.; Hoogenboom, R.L.; Portier, L.; Gerssen, A. BPA, BADGE and analogues: A new multi-analyte LC-ESI-MS/MS method for their determination and their in vitro (anti)estrogenic and (anti)androgenic properties. Chemosphere 2019, 221, 246-253. [CrossRef]

78. Rosenmai, A.K.; Dybdahl, M.; Pedersen, M.; Van Vugt-Lussenburg, B.M.A.; Wedebye, E.B.; Taxvig, C.; Vinggaard, A.M. Are structural analogues to bisphenol a safe alternatives? Toxicol. Sci. 2014, 139, $35-47$. [CrossRef]

79. Roelofs, M.J.E.; van den Berg, M.; Bovee, T.F.H.; Piersma, A.H.; Van Duursen, M.B.M. Structural bisphenol analogues differentially target steroidogenesis in murine MA-10 Leydig cells as well as the glucocorticoid receptor. Toxicology 2015, 329, 10-20. [CrossRef]

80. Wu, L.H.; Zhang, X.M.; Wang, F.; Gao, C.J.; Chen, D.; Palumbo, J.R.; Guo, Y.; Zeng, E.Y. Occurrence of bisphenol $\mathrm{S}$ in the environment and implications for human exposure: A short review. Sci. Total Environ. 2018, 615, 87-98. [CrossRef]

81. Siracusa, J.S.; Yin, L.; Measel, E.; Liang, S.; Yu, X. Effects of bisphenol A and its analogs on reproductive health: A mini review. Reprod. Toxicol. 2018, 79, 96-123. [CrossRef]

82. Qui, W.; Fang, M.; Liu, C.; Zheng, C.; Chen, B.; Wang, K.J. In vivo actions of bisphenol F on the reproductive neuroendocrine system after long-term exposure in zebrafish. Sci. Total Environ. 2019, 15, 995-1002. 
83. Shi, M.; Sekulovski, N.; MacLean, J.A., 2nd; Hayashi, K. Prenatal Exposure to Bisphenol A Analogues on Male Reproductive Functions in Mice. Toxicol Sci. 2018, 163, 620-631. [CrossRef]

84. Ullah, A.; Pirzada, M.; Jahan, S.; Ullah, H.; Turi, N.; Ullah, W.; Siddiqui, M.F.; Zakria, M.; Lodhi, K.Z.; Khan, M.M. Impact of low-dose chronic exposure to bisphenol A and its analogue bisphenol B, bisphenol F and bisphenol $S$ on hypothalamo-pituitary-testicular activities in adult rats: A focus on the possible hormonal mode of action. Food Chem. Toxicol. 2018, 121, 24-36. [CrossRef]

85. Shi, M.; Sekulovski, N.; MacLean, J.A.; Whorton, A.; Hayashi, K. Prenatal Exposure to Bisphenol A Analogues on Female Reproductive Functions in Mice. Toxicol. Sci. 2019, 168, 561-571. [CrossRef]

86. Kolla, S.; Morcos, M.; Martin, B.; Vandenberg, L.N. Low dose bisphenol S or ethinyl estradiol exposures during the perinatal period alter female mouse mammary gland development. Reprod. Toxicol. 2018, 78, 50-59. [CrossRef]

87. Zhou, D. Ecotoxicity of bisphenol S to Caenorhabditis elegans by prolonged exposure in comparison with bisphenol A. Environ. Toxicol. Chem. 2018, 37, 2560-2565. [CrossRef]

88. Desdoits-Lethimonier, C.; Lesné, L.; Gaudriault, P.; Zalko, D.; Antignac, J.P.; Deceuninck, Y.; Platel, C.; Dejucq-Rainsford, N.; Mazaud-Guittot, S.; Jégou, B. Parallel assessment of the effects of bisphenol A and several of its analogs on the adult human testis. Hum. Reprod. 2017, 32, 1465-1473. [CrossRef]

89. Lee, J.; Kim, S.; Choi, K.; Ji, K. Effects of bisphenol analogs on thyroid endocrine system and possible interaction with 17ß-estradiol using GH3 cells. Toxicol. Vitr. 2018, 53, 107-113. [CrossRef]

90. Castro, B.; Sánchez, P.; Torres, J.M.; Ortega, E. Bisphenol A, bisphenol F and bisphenol S affect differently $5 \alpha$-reductase expression and dopamine-serotonin systems in the prefrontal cortex of juvenile female rats. Environ. Res. 2015, 142, 281-287. [CrossRef]

91. Mokra, K.; Woźniak, K.; Bukowska, B.; Sicińska, P.; Michałowicz, J. Low-concentration exposure to BPA, BPF and BPAF induces oxidative DNA bases lesions in human peripheral blood mononuclear cells. Chemosphere 2018, 201, 119-126. [CrossRef]

92. Molina-Molina, J.M.; Amaya, E.; Grimaldi, M.; Sáenz, J.M.; Real, M.; Fernández, M.F.; Balaguer, P.; Olea, N. In vitro study on the agonistic and antagonistic activities of bisphenol-S and other bisphenol-A congeners and derivatives via nuclear receptors. Toxicol. Appl. Pharmacol. 2013, 272, 127-136. [CrossRef]

93. Naderi, M.; Wong, M.Y.L.; Gholami, F. Developmental exposure of zebrafish (Danio rerio) to bisphenol-S impairs subsequent reproduction potential and hormonal balance in adults. Aquat. Toxicol. 2014, 148, 195-203. [CrossRef]

94. Stroheker, T.; Chagnon, M.C.; Pinnert, M.F.; Berges, R.; Canivenc-Lavier, M.C. Estrogenic effects of food wrap packaging xenoestrogens and flavonoids in female Wistar rats: A comparative study. Reprod. Toxicol. 2003, 17, 421-432. [CrossRef]

95. Darbre, P.D. Endocrine Disruptors and Obesity. Curr. Obes. Rep. 2017, 6, 18-27. [CrossRef]

96. Wassenaar, N.H.; Trasando, L.; Legler, J. Systematic Review and Meta-Analysis of Early-Life Exposure to Bisphenol A and Obesity-Related Outcomes in Rodents. Environ. Health Perspect. 2017, 125, 106001. [CrossRef]

97. Legeay, S.; Faure, S. Is bisphenol A an environmental obesogen? Fund. Clin. Pharmacol. 2017, 31, 594-609. [CrossRef]

98. Riu, A.; Grimaldi, M.; Le Maire, A.; Bey, G.; Phillips, K.; Boulahtouf, A.; Perdu, E.; Zalko, D.; Bourguet, W.; Balaguer, P. Peroxisome proliferator-activated receptor gamma is a target for halogenated analogues of bisphenol A. Environ. Health Perspect. 2011, 119, 1227-1232. [CrossRef]

99. Zheng, S.; Shi, J.; Zhang, J.; Yang, Y.; Hu, J.; Shaon, B. Identification of the disinfection byproducts of bisphenol $\mathrm{S}$ and the disrupting effect on peroxisome proliferator-activated receptor gamma (PPARg) induced by chlorination. Water Res. 2018, 132, 167-176. [CrossRef]

100. Boucher, J.G.; Ahmed, S.; Atlas, E. Bisphenol S induces adipogenesis in primary human preadipocytes from female donors. Endocrinology 2016, 157, 1397-1407. [CrossRef]

101. Verbanck, M.; Canouil, M.; Leloire, A.; Dhennin, V.; Coumoul, X.; Yengo, L.; Froguel, P.; Poulain-Godefroy, O. Low-dose exposure to bisphenols $\mathrm{A}, \mathrm{F}$ and $\mathrm{S}$ of human primary adipocyte impacts coding and non-coding RNA profiles. PLoS ONE 2017, 12, e0179583. [CrossRef]

102. Ahmed, S.; Atlas, E. Bisphenol S- and bisphenol A-induced adipogenesis of murine preadipocytes occurs through direct peroxisome proliferatoractivated receptor gamma activation. Int. J. Obes. 2016, 40, 1566-1573. [CrossRef] 
103. Ivry Del Moral, L.; Le Corre, L.; Poirier, H.; Niot, I.; Truntzer, T.; Merlin, J.F.; Rouimi, P.; Besnard, P.; Rahmani, R.; Chagnon, M.C. Obesogen effects after perinatal exposure of 4,4'-sulfonyldiphenol (Bisphenol S) in C57BL/6 mice. Toxicology 2016, 357, 11-20. [CrossRef]

104. Charisiadis, P.; Andrianou, X.D.; van der Meer, T.P.; den Dunnen, W.F.A.; Swaab, D.F.; Wolffenbuttel, B.H.R.; Makris, K.C.; van Vliet-Ostaptchouk, J.V. Possible obesogenic effects of bisphenols accumulation in the human brain. Sci. Rep. 2018, 8, 1-10. [CrossRef]

(C) 2019 by the authors. Licensee MDPI, Basel, Switzerland. This article is an open access article distributed under the terms and conditions of the Creative Commons Attribution (CC BY) license (http://creativecommons.org/licenses/by/4.0/). 